\title{
Prawa pacjenta jako korelat obowiązków lekarza oraz prawne skutki ich naruszenia
}

\section{Patient's rights as a correlate of the physician's responsibilities and legal consequences of their violation}

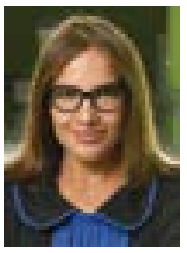

\section{Kamila Kocańda}

Instytut Nauk Medycznych, Uniwersytet Jana Kochanowskiego w Kielcach, Wojewódzki Szpital Zespolony w Kielcach

\section{Streszczenie}

Prawa pacjenta dotyczą wszystkich etapów procesu udzielania świadczeń zdrowotnych oraz różnych jego aspektów, zarówno standardu świadczeń, jak i okoliczności związanych z ich udzielaniem. Poszkodowany może egzekwować od lekarza lub podmiotu leczniczego zadośćuczynienie pieniężne gdy dojdzie do naruszenia jego praw jako pacjenta bez względu na to, czy doszło do wystąpienia szkody rozumianej jako błąd w sztuce medycznej.

Słowa kluczowe: prawa pacjenta, roszczenie, zadośćuczynienie

Folia Cardiologica 2018; 13, 4: 391-394

\section{Wprowadzenie}

Zgodnie z definicją ustawową, za pacjenta uważa się osobę zwracającą się o udzielenie świadczeń zdrowotnych lub korzystającą ze świadczeń zdrowotnych udzielanych przez podmiot leczniczy lub osobę wykonującą zawód medyczny. Prawa pacjenta, definiujące zakres uprawnień związanych z udzielaniem świadczeń zdrowotnych, obowiązują w równym stopniu w sektorze publicznym, jak i na prywatnym rynku usług medycznych. Odnoszą się one do wszystkich etapów procesu udzielania świadczeń zdrowotnych oraz różnych jego aspektów, tak w sferze standardu świadczeń, jak i okoliczności związanych z ich udzielaniem. Istotne znaczenie ma tu fakt przewidzianych przez ustawodawce konsekwencji prawnych naruszenia praw pacjenta. Może on egzekwować od lekarza lub podmiotu leczniczego zadośćuczynienie pieniężne bez względu na to, czy doszło do wystąpienia szkody rozumianej jako błąd w sztuce medycznej.

\section{Kategorie praw pacjenta}

Pośród licznych praw pacjenta wypada zwrócić uwagę na te, które sprawiają wrażenie najbardziej istotnych z punktu widzenia standardu organizacyjnego w opiece zdrowotnej. Pacjent ma zatem prawo do świadczeń zdrowotnych odpowiadających wymaganiom aktualnej wiedzy medycznej. Jak wskazuje się w orzecznictwie, przez „wiedzę medyczną, która spełnia kryterium aktualności”, rozumieć należy wiadomości uzyskiwane przez lekarza w czasie studiów, dostępne w szeroko rozumianych podręcznikach, ale także kompetencje uzyskane z racji rozwoju naukowo-technicznego, wzbogacane dzięki doskonaleniu umiejętności zawodowych ${ }^{1}$. Obowiązek wykonywania zawodu zgodnie ze wskazaniami aktualnej wiedzy medycznej wyartykułowany jest wprost w ustawie o zawodach lekarza i lekarza dentysty. W odniesieniu do świadczeń zdrowotnych rzeczowych: stosowanych leków oraz wyrobów medycznych,

${ }^{1}$ Wyrok SA w Łodzi z dnia 27 listopada 2014 r., I ACa 745/14, LEX nr 521717624. 
oznacza to obowiązek uzyskania dostatecznych informacji o stosowanym produkcie, w tym informacji takich jak charakterystyka produktu leczniczego czy instrukcja użycia ${ }^{2}$. „Aktualna wiedza medyczna” jest kategorią obiektywną, która wymaga jednak intersubiektywnej weryfikacji zgłaszanych twierdzeń ${ }^{3}$.

Prawo do przejrzystej, obiektywnej, opartej na kryteriach medycznych, procedury ustalającej kolejność dostępu do tych świadczeń może zostać w sposób prawnie uzasadniony limitowane, a to w sytuacji ograniczonych możliwości udzielenia odpowiednich świadczeń zdrowotnych. Ustawodawca przesądza, że świadczenia opieki zdrowotnej w szpitalach i w ambulatoryjnej opiece specjalistycznej udzielane są według kolejności zgłoszenia w dniach i godzinach ich udzielania przez świadczeniodawcę, który zawarł umowę o udzielanie świadczeń opieki zdrowotnej (tzw. listy oczekujących). Z pewnością w większości przypadków czas oczekiwania na udzielnie świadczenia nie spełnia oczekiwań pacjentów, a niejednokrotnie nie koreluje też z możliwościami świadczeniodawców, bowiem jego podstawową determinantą jest wielkość środków finansowych w systemie opieki zdrowotnej. W takiej sytuacji właściwym adresatem roszczenia z tytułu naruszenia tego prawa wydaje się być płatnik świadczeń gwarantowanych jako organizator systemu opieki zdrowotnej.

Ograniczone (finansowo) możliwości udzielenia świadczenia, które usprawiedliwiają odraczanie świadczeń planowych, nie znajduje zastosowania w przypadku świadczeń nagłych, które muszą być udzielone bez zbędnej zwłoki, co jest potwierdzone innym z kluczowych praw pacjenta, a mianowicie prawem do natychmiastowego udzielenia świadczeń zdrowotnych ze względu na zagrożenie zdrowia lub życia. Podmiot leczniczy nie może odmówić udzielenia świadczenia zdrowotnego osobie, która potrzebuje natychmiastowego udzielenia takiego świadczenia ze względu na zagrożenie życia lub zdrowia. W orzecznictwie wskazuje się, że obowiązek ten ma charakter bezwzględny i wyprzedza ograniczenia wynikające z umów o udzielanie świadczeń opieki zdrowotnej, przez co kosztami świadczeń udzielonych ubezpieczonym w warunkach przymusu ustawowego należy obciążyć Narodowy Fundusz Zdrowia jako podmiot zarządzający środkami publicznymi, z których powinny one być pokryte ${ }^{4}$. Lekarz ma obowiązek udzielać pomocy lekarskiej w każdym przypadku, gdy zwłoka w jej udzieleniu mogłaby spowodować niebezpieczeństwo utraty życia, ciężkiego uszkodzenia ciała lub ciężkiego rozstroju zdrowia, jak również w innych niecierpiących zwłoki przypadkach. Według literatury prawnej określenie „inne przypadki nie

${ }^{2}$ Wyrok Sądu Apelacyjnego w Warszawie z dnia 4 marca 2015 r., I ACa 515/14, LEX nr 1665867.

'Widłak T., Interpretacja klauzuli 'aktualna wiedza medyczna’ w polskim prawie - zarys zagadnień epistemologicznych i metodologicznych, Gdańskie Studia Prawnicze 2017; XXXVIII: 603.

${ }^{4}$ Wyrok Sądu Najwyższego z dnia 12 marca 2009 r., V CSK 272/08, LEX nr 530613. cierpiące zwłoki” interpretować należy w oderwaniu od grożących następstw, jako wszystkie sytuacje, w których pomoc lekarska jest konieczna niezwłocznie ${ }^{5}$.

Zaniechanie udzielenia świadczeń zdrowotnych może uzasadniać odpowiedzialność podmiotu leczniczego wobec finansującego te świadczenia płatnika w sytuacji, gdy odmowa udzielenia świadczenia była bezpodstawna. Wedle art. 162 Kodeksu karnego, kto człowiekowi znajdującemu się w położeniu grożącym bezpośrednim niebezpieczeństwem utraty życia albo ciężkiego uszczerbku na zdrowiu nie udziela pomocy, mogąc jej udzielić bez narażenia siebie lub innej osoby na niebezpieczeństwo utraty życia albo ciężkiego uszczerbku na zdrowiu, podlega karze pozbawienia wolności do lat 3. Z przepisów Kodeksu etyki lekarskiej wynika, że lekarz nie może odmówić pomocy lekarskiej w przypadkach nie cierpiących zwłoki, jeśli pacjent nie ma możliwości uzyskania jej ze strony instytucji powołanych do udzielania pomocy.

Pacjentowi przysługuje prawo do świadczeń zdrowotnych udzielanych z należytą starannością przez podmioty udzielające świadczeń zdrowotnych. „Należyta staranność” oznacza działanie właściwie dobrane do kwalifikacji lekarza, do jego doświadczenia i konkretnej sytuacji, przy uwzględnieniu całokształtu okoliczności istniejących w chwili dokonywania zabiegu medycznego. Kryteria określające poziom wymagań w zakresie należytej staranności podlegają gradacji, ale w każdym przypadku musza one być obiektywne, natomiast poziom wymagań musi wyznaczać stan wiedzy medycznej obejmujący nie tylko metody leczenia, ale również stosowanie leków oraz wyposażenie medyczne placówek ochrony zdrowia. Kryterium należytej staranności lekarza, choć odnosi się do elastycznego wzorca oceny, nie pozwala, by wymagania zawodowe obniżyć poniżej pewnej granicy, po przekroczeniu której lekarz nie powinien być traktowany jako dobry fachowiec. Jeśli odpowiada on za niedochowanie koniecznej staranności choćby w najmniejszym stopniu, to w istocie zaprzecza idei staranności zawodowej jako cechy koniecznej dla tak zwanego „dobrego lekarza”. Staranność lekarska powinna zatem stale rosnąć, jako że każdy lekarz powinien być specjalistą co najmniej dobrym. Wynika to ze szczególnego wymiaru etosu zawodu lekarskiego i z jego doniosłego znaczenia społecznego ${ }^{6}$.

\section{Konsekwencje prawne naruszenia praw pacjenta}

W razie zawinionego naruszenia praw pacjenta, sąd może przyznać poszkodowanemu odpowiednią kwotę tytułem zadośćuczynienia pieniężnego za doznaną krzywdę. Powyższe

\footnotetext{
${ }^{5}$ Wyrok Sądu Apelacyjnego w Krakowie z dnia 15 stycznia 2014 r., I ACa 1363/13, LEX nr 1540865.

${ }^{6}$ Wyrok Sądu Apelacyjnego w Poznaniu z dnia 5 marca 2014 r., I ACa 1274/13, Orzecznictwo Sądów Apelacyjnych 2014, 8: 36.
} 
nie dotyczy zawinionego naruszenia prawa pacjenta do informacji o rodzaju i zakresie świadczeń zdrowotnych, dostępu do dokumentacji medycznej oraz zgłaszania działań niepożądanych produktów leczniczych. Wyrządzenie krzywdy, stanowiącej podstawę dla żądania zadośćuczynienia pieniężnego, nastąpić może na etapie diagnozowania, terapii, jak i rehabilitacji . Znaczenie powołanego przepisu ustawy polega na tym, że wskazuje on, expressis verbis, te naruszenia praw pacjenta, które przesądzają o naruszeniu dobra osobistego. W związku z tym pokrzywdzony nie musi udowadniać, że w jego przypadku doszło do naruszenia prawnie chronionego dobra osobistego - wystarczy wskazać konkretne naruszenie praw pacjenta ${ }^{8}$.

Jeżeli więc dokonano zabiegu operacyjnego bez zgody pacjenta, lecz nie doznał on żadnej szkody, gdyż operacja była korzystna dla jego stanu zdrowia, to pacjent może żądać jedynie zadośćuczynienia za naruszenie jego prawa do autonomicznego wyrażenia zgody na interwencję medyczną. Jeśli natomiast pacjent doznał szkody, to lekarz (szpital) jest zobowiązany wynagrodzić mu szkodę majątkową i niemajątkową. Naruszenie praw pacjenta, na przykład przez nieudzielenie informacji o zakażeniu, które podczas pobytu w pozwanym szpitalu zostało wykryte, stanowi podstawę do zasądzenia od szpitala zadośćuczynienia ${ }^{9}$. Rekompensata finansowa przysługuje zatem jedynie w przypadku zawinionego naruszenia prawa, choćby nie wiązał się z tym żaden uszczerbek dla pacjenta.

Określając wysokość zadośćuczynienia, sąd powinien wziąć pod uwagę rozmiar doznanego uszczerbku niemajątkowego, przez co rozumieć należy stopień oraz czas trwania cierpień fizycznych i psychicznych. Sąd powinien też uwzględnić inne okoliczności, które mogą mieć wpływ na zakres przeżywanych cierpień, takich jak na przykład nieodwracalność następstw naruszenia prawa, rodzaj pracy wykonywanej przez poszkodowanego, jego szanse na przyszłość, poczucie nieprzydatności społecznej, wiek, płeć, bezradność życiową oraz inne czynniki podobnej natury $^{10}$. W jednym z wyroków sąd przyznał zadośćuczynienie za powikłanie przy operacji, mimo że była ona przeprowadzona prawidłowo, powikłania nie można było uniknąć, a zabieg był konieczny ze względu na zagrożenie życia pacjentki - nie mogła ona nie poddać się operacji, czego miała świadomość. Sąd jednak uznał, że pacjentka nie została poinformowana o ryzyku wystąpienia powikłań, przez co zostało naruszone jej prawo do informacji,

\footnotetext{
${ }^{7}$ Wasilewska E, Zobiektywizowany sposób oceny rozmiaru krzywdy przy ustalaniu zadośćuczynienia pienieżnego na rzecz poszkodowanego pacjenta, Ius Novum 2017; 11(3): 101.

${ }^{8}$ Wyrok Sądu Apelacyjnego w Łodzi z dnia 12.02.2015 r., I ACa 745/14, LEX nr 1623928.

${ }^{9}$ Nesterowicz M, Glosa do wyroku s.apel. z dnia 10 marca 2015 r., VI ACa 651/14, PiM, 2016; 4: 123-130.

${ }^{10}$ Wasilewska E, Zobiektywizowany sposób oceny rozmiaru krzywdy przy ustalaniu zadośćuczynienia pieniężnego na rzecz poszkodowanego pacjenta, lus Novum 2017; 3: 101-121.
}

a zgoda na zabieg nie spełniała ustawowego kryterium „świadomości" ${ }^{11}$.

\section{Ograniczenie korzystania z praw pacjenta}

Kierownik podmiotu udzielającego świadczeń zdrowotnych lub upoważniony przez niego lekarz może ograniczyć korzystanie z praw pacjenta w przypadku wystąpienia zagrożenia epidemicznego lub ze względu na bezpieczeństwo zdrowotne innych pacjentów. W przypadku prawa do kontaktu osobistego, telefonicznego lub korespondencyjnego z innymi osobami, ograniczenia mogą wynikać także ze względu na możliwości organizacyjne podmiotu leczniczego. Ograniczenie prawa do kontaktu ze względu na możliwości organizacyjne podmiotu leczniczego może dotyczyć sytuacji, w której realizacja tego prawa będzie nieść ze sobą rzeczywiste utrudnienia dotyczące organizacji udzielania świadczeń zdrowotnych dla pacjenta lub innych chorych. Jest to wprawdzie zwrot nieokreślony, kategoria ocenna, ale jego celem powinno być godzenie interesów wszystkich pacjentów korzystających z usług danego podmiotu. Powyższe oznacza, iż skorzystanie z prawa do kontaktu osobistego z dzieckiem nie może kolidować z normalną pracą podmiotu, utrudniać udzielania świadczeń zdrowotnych, naruszać praw innych pacjentów, w szczególności prawa do poszanowania intymności oraz do ciszy i spokoju. Jak wskazuje Rzecznik Praw Pacjenta, będący centralnym organem administracji stojącym na straży przestrzegania praw pacjenta, kierownik placówki medycznej, korzystający z możliwości odmowy realizacji lub ograniczenia praw pacjenta, musi podać należyte uzasadnienie swej decyzji oraz traktować ograniczenie czy też odmowę realizacji praw pacjenta jako wyjątek.

\section{Wnioski}

Przestrzeganie praw pacjenta określonych w ustawie jest obowiązkiem organów władzy publicznej właściwych w zakresie ochrony zdrowia, Narodowego Funduszu Zdrowia, podmiotów udzielających świadczeń zdrowotnych, osób wykonujących zawód medyczny oraz innych osób uczestniczących w udzielaniu świadczeń zdrowotnych. Żądanie zapłaty zadośćuczynienia z tytułu naruszenia praw pacjenta przysługuje poszkodowanemu z samego faktu naruszenia jego praw jako pacjenta, a przyznawane zadośćuczynienie ma stanowić kompensatę krzywdy z tytułu naruszenia dóbr osobistych $^{12}$. W ramach roszczenia o zadośćuczynienie pieniężne za naruszenie praw pacjenta, wystarczające jest wykazanie zawinionego zachowania personelu leczniczego jednostki medycznej, które naruszyło określone prawa pacjent. Zadośćuczynienie ma służyć kompensacie krzywdy

${ }^{11}$ Wyrok Sądu Okręgowego w Krakowie z 30 grudnia 2003 r., I C 110/2002 Prawo i Medycyna 2006; 1.

${ }^{12}$ Wyrok Sądu Apelacyjnego w Lublinie I ACa 916/14, LEX nr 1711484 
w związku z naruszeniem praw pacjenta ${ }^{13}$, a nadto ma także na celu złagodzenie doznanych cierpień, przy jednoczesnym uwzględnieniu, że ma ono jednorazowy charakter. Okoliczności wpływające na wysokość tego świadczenia, to między innymi: dramatyzm doznań, cierpienia moralne oraz wstrząs psychiczny ${ }^{14}$. Mając zatem na względzie, iż naruszenie praw pacjenta skutkować może odpowiedzialnością niezależnie od postępowania medycznego, które musi cechować się przymiotem lege artis, należy dążyć do ich przestrzegania w procesie udzielania świadczeń zdrowotnych.

\section{Konflikt interesów}

Brak.

\section{Abstract}

Patients' rights refer to all stages of the process of providing healthcare services and its various aspects, both in terms of the standard of healthcare services and the circumstances related to their provision. The patient can demand financial compensation from the doctor or healthcare institution in the event that his or her rights as a patient are violated regardless of whether or not there is harm to the patient in connection with this type of violation, understood as a medical error.

Key words: patients' rights, claim, compensation

Folia Cardiologica 2018; 13, 4: 391-394

\section{Piśmiennictwo}

1. Szpringer M, Chmielewski J, Kosecka J, et al. Poziom satysfakcji pacjenta jako jeden z aspektów jakości opieki medycznej. Medycyna Ogólna i Nauki o Zdrowiu. 2015; 21(2): 132-137, doi: 10.5604/20834543.1152908.

2. Kmieciak B. Prawa pacjenta z perspektywy funkcjonalnej refleksji. Filozofia Publiczna i Edukacja Demokratyczna. 2018; 3(1): 169-191, doi: 10.14746/fped.2014.3.1.9.

3. International Committee of Medical Journal Editors. Protection of patients' rights to privacy. BMJ. 1995; 311(7015): 1272, indexed in Pubmed: 11644736.

4. Jacek A. Jacek A, Ożóg K, Respecting patient's rights by medical staff, Hygeia Public Health. 2012; 47(3): 264-271.

5. Mastaneh Z, Mouseli L. Patients' awareness of their rights: insight from a developing country. Int J Health Policy Manag. 2013; 1(2): 143-146, doi: 10.15171/ijhpm.2013.26, indexed in Pubmed: 24596854.

6. Wasilewska E. Wasilewska E, Zobiektywizowany sposób oceny rozmiaru krzywdy przy ustalaniu zadośćuczynienia pienieżnego na rzecz poszkodowanego pacjenta, lus Novum. 2017; 11(3): 101.

7. Łaska-Formejster A. Pacjent w sieci zależności. Społeczny kontekst praw i autonomii pacjenta, Łódź 2015: i.

8. Serwach M. Serwach M, Prawa pacjenta do świadczeń zdrowotnych i ich kontekst, Polityka Społeczna. 2011; 1 : 11.

9. Wyrok Sądu Najwyższego z dnia 18 stycznia 2013 r., IV CSK 431/12, LEX nr. 1275006.

10. Wyrok Sądu Najwyższego z dnia 4 listopada 2016r., I CSK 739/15, LEX nr. 2166373.

11. Ciechorski J. Udostępnianie dokumentacji po śmierci pacjenta - uwagi na tle wyroku Naczelnego Sądu Administracyjnego z dnia 17 września 2013 r. sygn. II OSK 1539/13, PiM. 2015; 4: 70-84.

12. Boratyńska M, Konieczniak P. Prawa pacjenta. Difin, Warszawa: 326-335.
13. Paszkowska M. Paszkowska M, Prawa pacjenta w szpitalu, Prz Med Uniw Rzeszow i NIL, Rzeszów 2011: 115-127.

14. Drozdowska U. Drozdowska U, Cywilnoprawna ochrona praw pacjenta, Warszawa: 141-152.

15. Paszkowska M. Paszkowska M, Rzecznik Praw Pacjenta w systemie ochrony prawnej, PPP, 2010; 7-8: 181-199.

16. Nesterowicz M. Glosa do wyroku s. apel. z dnia 10 marca 2015 r., VI ACa 651/14, PiM. 2016; 4: 123-130.

17. Nesterowicz M. Glosa do wyroku SN z dnia 3 grudnia 2009 r., II CK 337/09, PiM. 2012; 2: 122-128.

18. Młynarski T. Młynarski T, Zadośćuczynienie pienieżne z tytułu naruszenia dóbr osobistych - wezłowe problemy z punktu widzenia ubezpieczeń odpowiedzialności cywilnej w świetle najnowszego orzecznictwa sadów, Rozprawy Ubezpieczeniowe. 2015; 18(1): 43.

19. Schain W. Patients' rights in decision making: The case for personalism versus paternalism in health care. Cancer. 1980; 46(S4): 1035-1041, doi: 10.1002/1097-0142(19800815)46:4+<1035::aid-cncr2820461329>3.0.c0;2-h.

20. Maciag A, Sakowska I. Maciag A, Sakowska I, Rola i prawa pacjenta w obszarze jakości usług zdrowotnych, Studia i Materiały - Wydział Zarządzania UW 2006: 50.

21. Bączyk-Rozwadowska K. Prawo pacjenta do informacji według przepisów polskiego prawa medycznego. Studia luridica Toruniensia. 2011; 9(0): 59, doi: 10.12775/sit.2011.013.

22. Witczak H, Witczak W. W sprawie zadośćuczynienia pieniężnego należnego pacjentom, Teka Kom. Praw. - OL PAN. 2010: 230-244.

23. Filarski T, Sroka T. Zrozumieć prawa pacjenta. Podstawowe wiadomości o organizacji systemu ochrony zdrowia w Polsce: Warszawa.

24. Nesterowicz M. Glosa do wyroku SN z dnia 27 kwietnia 2012 r., V CSK 142/11, OSP. 2013; 6: 61.

25. Wyrok Sądu Najwyższego z dnia 29 maja 2007 r., V CSK 76/07, OSNC, 2008; 7-8: 91.

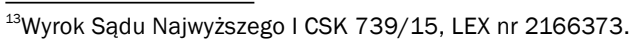

${ }^{14}$ Wyrok Sądu Apelacyjnego w Łodzi, I ACa 768/17, LEX nr 2478705.
} 